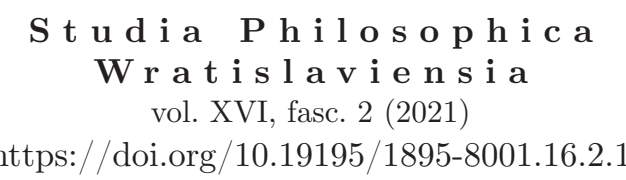

MAGDALENA KOZAK

ORCID: 0000-0002-2549-8007

Akademia Ignatianum w Krakowie

\title{
Czas jako sposób bycia istoty śmiertelnej - polemika Lévinasa z Heideggerem
}

\section{Time as a mode of being of a mortal entity - Lévinas' discussion with Heidegger}

\begin{abstract}
The aim of my article is to juxtapose and compare the concept of man immersed in the finite (Heidegger) and on the other hand transcending towards the infinite (Levinas). My task is to extract and analyse the fabulously contrasting moments in the thought of Heidegger and Levinas on the question of the connection and interpenetration of time and death. Both philosophers grow out of the phenomenological tradition, but their analyses of the problem of the connection between time and death go in different directions. The experiences of time and death are inextricably linked, but for Heidegger time is the ontological horizon of being, and for Levinas time is a way of being beyond being. For Heidegger, dying is about coming to the fullness of being. For Levinas, facing death is a struggle and even a war, a transcendence towards the infinite. While for Heidegger death is the completion of the end, for Levinas death means an encounter with radical otherness, it is an opening and not a closing.
\end{abstract}

Keywords: time, death, finitude, infinity, transcendence, Heidegger, Levinas, sense 
Ostatni odcinek drogi zostanie przebyty beze mnie, czas śmierci płynie pod prąd ${ }^{1}$.

E. Lévinas

\section{Wprowadzenie}

Pytanie o naturę czasu otwiera przed człowiekiem wielki problem intelektualny, zmuszając go do namysłu nad swoją własną kondycją w świecie. Wśród wielu myślicieli, którzy próbowali zgłębić ten problem, skupiając się właśnie na perspektywie czasowości, szczególną uwagę może wzbudzić refleksja dwóch wielkich filozofów: Martina Heideggera i Emmanuela Lévinasa. Śledząc teksty francuskiego filozofa poświęcone temu zagadnieniu, nie trudno zauważyć jego konfrontacyjne względem ujęcia niemieckiego filozofa podejście do koncepcji czasu. Być może właśnie to pole dyskusji najwyraźniej pokazuje różnice w perspektywie spoglądania na człowieka z jednej strony zanurzonego w skończoności (Heidegger), a z drugiej, wykraczającego ku nieskończoności (Lévinas). W poniższym artykule chciałabym skupić się jedynie na tych najbardziej kontrastujących z sobą momentach w myśli Heideggera i Lévinasa w ujmowaniu kwestii powiązania i przenikania się czasu oraz śmierci. Obydwaj filozofowie wyrastają z tradycji fenomenologicznej, ale ich analizy problematyki czasu i śmierci, mimo wspólnych korzeni, zdają się podążać w różnych kierunkach. Zarówno dla Heideggera, jak i dla Lévinasa doświadczenie czasu nierozerwalnie połączone jest z doświadczeniem śmierci, co wydaje się zbliżać ich do siebie na płaszczyźnie egzystencjalnej, ale dla każdego z nich to doświadczenie przebiegać będzie na inny sposób. Celem artykułu jest zestawienie z sobą tych dwóch kierunków myślenia, porównanie i — mimo wspólnej tradycji fenomenologicznej, z której wyrośli, oraz łączącej ich perspektywy egzystencjalnej - przeanalizowanie punktów najbardziej spornych i sytuujących ich w dwóch odmiennych sposobach myślenia o człowieku. Czytając teksty Lévinasa poświęcone problematyce czasu, łatwo zauważyć, iż swoje ujęcie tego problemu buduje on w opozycji do poglądów Heideggera, a można nawet zaryzykować stwierdzenie: na radykalnej krytyce jego stanowiska. O ile dla Heideggera czas jawi się jako ontologiczny horyzont bycia bytu, o tyle dla Lévinasa czas oznaczać będzie sposób bycia poza byciem. „Czas nie jest ontologicznym horyzontem bycia bytu, ale sposobem [bycia] poza byciem, relacją »myśli « do Innego [...], relacja do całkowicie Innego, do Transcendentnego, do Nieskończoności"'. Jeżeli dla Heideggera czas stanowi ten wymiar ludzkiej egzystencji, który ją domyka, dopełnia, to dla Lévinasa czas jawi się jako relacja z tym, co nieskończone, z tym, co nie pozwala się pojąć (compren$d r e)^{3}$ i ogarnąć w żaden sposób.

${ }^{1}$ E. Lévinas, Całość i nieskończoność, tłum. M. Kowalska, Warszawa 2002, s. 282.

${ }^{2}$ E. Lévinas, Czas i to, co inne, tłum. J. Migasiński, Warszawa 1999, s. 7.

${ }^{3}$ Czasownik, którego używa w tym kontekście Lévinas - comprendre, oznacza w dosłownym tłumaczeniu „rozumieć”, „pojmować”, ale zawiera w sobie rdzeń prendre, który oznacza „chwytać”, „zawładnąć". 
Zasadnicza teza Lévinasa, której broni on we wszystkich swoich tekstach poświęconych zagadnieniu czasu, polegałaby na:

Pomyśleniu czasu nie jako jakiejś degradacji wieczności, ale jako relacji do tego, co będąc samo z siebie czymś nie dającym się zasymilować, absolutnie innym, nie pozwalałoby się zasymilować przez doświadczenie, albo jako relacji do tego, co będąc samo z siebie czymś nieskończonym, nie pozwalałoby się pojąc $c^{4}$.

Lévinas wielokrotnie pisze o nieprzewidywalności śmierci, o niemożliwości uchwycenia jej, nawet o pewnej przemocowości, która pojawia się w doświadczeniu śmierci ${ }^{5}$. Śmierć jawi się dla niego jako przeciwnik nierówny, przychodzący z innego wymiaru a konfrontacja z nim jako niesprawiedliwa, bo z góry skazująca człowieka na przegraną. O ile dla Heideggera umieranie jawi się jako niedojrzałość owocu, który zmierza do swej dojrzałości ${ }^{6}$, a śmierć jako naturalne dopełnienie całości bytu, jako meta dobiegania do kresu porównana do ostatniej kwadry w pełni księżyca ${ }^{7}$, o tyle Lévinas opisuje wychodzenie naprzeciw śmierci jako walkę czy nawet wojnę: „Walka jest już albo jeszcze wojną, w której między walczącymi stronami zieje otchłań transcendencji — otchłań, przez którą przychodzi i uderza

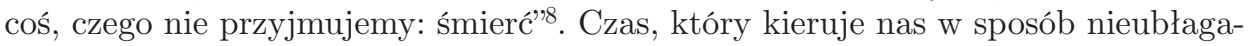
ny w stronę śmierci, naznacza człowieka koniecznością mierzenia się, sprzeciwu, ze świadomością nieuchronnej porażki na finale tej konfrontacji.

Jeżeli dla Heideggera bycie-rzuconym-w-świat oznacza bycie-ku-śmierci rozumiane jako bycie-ku-kresowi, jako ,jeszcze-nie”, to czas oznacza tutaj modalność skończonego bycia, skończonego śmiercią, która dotyka nas jako owy kres. Lévinas przyjmuje inną perspektywę: czas pojmowany jest przez niego jako transcendowanie ku nieskończoności, jako relacja z tym, co radykalnie inne ode mnie, jako otwarcie a nie jako zamknięcie. Czas nie przebiega więc w sposób linearny jak u Heideggera, „nie przypomina linii prostej intencjonalnego promienia. Jego sposób ukazywania znaczenia, napiętnowany tajemnicą śmierci, polega na poruszaniu się nie wprost, poprzez wkroczenie w etyczną przygodę relacji do innego człowieka"9. Śmierć dla Lévinasa nie oznacza przejścia ze stanu bycia-rzuconym-w-świat w stan nicości, ale relację z tym co inne, z tym co radykalnie inne. Inne, czyli nie dające się zrozumieć, ogarnąć, posiąść, z tym, co niepojmowalne. Śmierć oznaczać będzie „,nie dającą się przyswoić tajemnicę", „pytanie bez danych” „,czysty moment”, „skandal”, „kryzys", „niepamiętną diachronię"10. Przyjrzyjmy się bliżej temu zagadnieniu.

${ }^{4}$ E. Lévinas, Czas i to, co inne, s. 9.

${ }^{5}$ Lévinas pisze: „Nieprzewidywalność śmierci polega na tym, że nie mieści się ona w żadnym horyzoncie. W żaden sposób nie można jej ująć. Śmierć zagarnia mnie, nie dając mi szansy, jaką daje walka, albowiem we wzajemnej walce mogę chwycić tego, kto mnie chwyta. Śmiertelność naraża mnie na przemoc absolutną, na zabójstwo pod osłoną nocy. Choć, prawdę mówiąc, już w walce walczę z niewidzialnym, gdyż nie jest ona tym samym, co zderzenie dwóch sił, którego wynik można przewidzieć i obliczyć"; E. Lévinas, Całość i nieskończoność, s. 280-281.

${ }^{6}$ M. Heidegger, Bycie $i$ czas, s. 307.

7 Ibidem.

${ }^{8}$ E. Lévinas, Całość i nieskończoność, s. 281.

${ }^{9}$ E. Lévinas, Czas i to, co inne, s. 12.

${ }^{10}$ Por. E. Lévinas, Bóg, śmierć i czas, tłum. J. Margański, Kraków 2008, s. 15. 


\section{Czym jest czas autentyczny?}

Powiązanie czasu i śmierci okazało się dla Lévinasa problematyką tak ważną, że cały swój cykl wykładów na Sorbonie wygłoszony w roku akademickim 1975-1976 poświęcił tej właśnie kwestii. W Polsce wykłady te ukazały się w postaci książki Bóg, śmierć, czas, ale już wiele lat wcześniej — w roku akademickim 1946-1947 w Collège Philosophique Lévinas wygłosił cztery wykłady poświęcone tematyce czasu, które ukazały się w Polsce pod tytułem Czas $i$ to, co inne. To najlepiej obrazuje jak bardzo istotne miejsce w twórczości Lévinasa zajmuje tematyka czasu i śmierci, a w pewnym sensie także konfrontacja z myślą Heideggera na tym gruncie. W swoich rozważaniach Lévinas wyraźnie opowiada się za pojmowaniem czasu rozumianego jako trwanie, uzasadniając swoje stanowisko niemożnością postawienia pytania „czym jest czas?”, ponieważ wtedy musielibyśmy przyjaćc, że czas jest bytem (être). Zatem pierwsze pytanie, które zdaje się przyświecać Lévinasowi brzmiałoby: czym jest czas autentyczny?, co stanowi oczywiste nawiązanie do bycia autentycznym w ujęciu Heideggera. Właśnie termin „trwanie” doskonale pasuje Lévinasowi, gdyż wyraża on pewną nie-intencjonalność, co francuski filozof rozumie jako niemożność mierzenia czasu. Owo trwanie czasu, rozumiane jako czas nie-zegarowy, niewymierny, niemierzalny, Lévinas ujmuje także jako bierność, będącą samą cierpliwością ${ }^{11}$. Dzięki takiemu podejściu Lévinas już na wstępie wyraźnie dystansuje się do heideggerowskiego ujęcia czasu, które francuski filozof widzi w perspektywie byt-niebyt ujmując w pytaniu:

Czy bycie w obliczu śmierci nie sprowadza się do ontologicznego dylematu bytu-niebytu? — oto pytanie, jakie tutaj zadajemy. Albowiem sprowadzenie śmierci do dylematu bytu-niebytu to dogmatyzm na odwrót, niezależnie od tego, jakie uczucia całe nieufne pokolenie żywi w stosunku do pozytywnego dogmatyzmu nieśmiertelności duszy uważanego za najsłodsze „opium dla ludu”12.

Dla Lévinasa śmierć nie jest tylko horyzontem bycia ani istotą bycia; nie daje się ona ująć jedynie w horyzoncie ontologicznym ${ }^{13}$. Lévinas nie godzi się także na rozpatrywanie śmierci w granicach czasu, jak chce tego Heidegger. Jeżeli Heidegger widzi bycie-ku-śmierci jako bycie-ku-kresowi rozumianemu jako nicość, to Lévinas nie godzi się także na ujęcie nicości jako równoważnika bycia. Co się z tym wiąże: czas nie jest jedynie tłem dla bycia czy też kierunkiem bycia zmierzającego ku nicości. „Co jednak otwiera się wraz ze śmiercią: nicość czy to co nieznane?”"14 — pyta znowu Lévinas. Jeżeli śmierć oznacza otwarcie, to znaczy, że czas się nie kończy w jej momencie. Śmierć jako cierpliwość czasu — wielokrotnie będzie używał tego określenia w swoich wykładach. Jeżeli pisze, że ,śmierć jest punktem, z którego czas czerpie swoją cierpliwość"15, to znaczy, że śmierć nie jest zwykłą negacją życia

11 Por. ibidem, s. 13.

12 E. Lévinas, Bóg, śmierć, czas, s. 15.

13 „Może wydać się dziwne, iż podważamy tu prawdę myśli, zgodnie z którą śmierć prowadzi albo do nicości, albo do bytu, jakbyśmy chcieli powiedzieć, że alternatywa bytu i nicości nie jest ostateczna"; E. Lévinas, Całość i nieskończoność, s. 280.

14 E. Lévinas, Bóg, śmierć $i$ czas, s. 15.

15 Ibidem, s. 14. 
i że czas nie domyka się w jej momencie. „Śmierć jako cierpliwość czasu” — na taką fenomenologiczną interpretacją Lévinas może się zgodzić.

\section{Otwarcie na śmierć — niepokój i czuwanie}

Na czym polega to otwarcie? Francuski filozof znowu konfrontuje się z Heideggerem, pisząc, że śmierć nie jest przejściem od bycia do już-nie-bycia na zasadzie czystego zanegowania. Śmierć nie jest zwykłym unicestwieniem bycia, nie jest przejściem w nicość, jak chce tego Heidegger. Owszem, śmierć jawi się jako odejście, ale odejście w nieznane, ku nowemu, ku innemu. Śmierć otwiera tajemnicę, sama jest częścią tej tajemnicy. Czas nie oznacza degradacji wieczności, ale relację do tego, czego nie da się zasymilować przez doświadczenie, relację z czymś tak odległym i radykalnie innym, że wykluczona zostaje możliwość nawet pomyślenia o tym w sposób całościowy i spójny. W tym kontekście śmierć jawi się jako odsłanianie tego, co wcześniej zakryte, a nie jako unicestwienie. Śmierć nie jest więc zakończeniem czy zamknięciem czasu - ona jest wtargnięciem w czas, ,,jakby w śmierci tkwił jakiś nadmiar"16. Śmierć nie jest więc odpowiedzią na moje wcześniejsze bycie-w-świecie, ale dopiero pytaniem (co się właśnie dokonuje? co dalej?). Jeżeli Lévinas nazywa ją otwartością, to otwartość sama w sobie jest zapytywaniem: „Nie wiadomo, kiedy nadejdzie śmierć. I co właściwie nadejdzie? Czym śmierć mi grozi? Nicością czy nowym początkiem? Nie wiem. Istota ostatniej chwili polega właśnie na niemożności poznania tego, co będzie, kiedy umrę. Absolutnie nie mogę uchwycić chwili śmierci — »nie leżącej w naszym zasięgu «"17. Można odnieść wrażenie, że Lévinas w wielu miejscach skłania się do osadzenia umierania i samej śmierci w perspektywie egzystencjalnej, podkreślając mnogością pytań retorycznych naszą bezbronność, bezsilność i bierność wobec doświadczenia krańcowego.

Moment śmierci odsłania się tutaj jako moment spotkania z innością, jako zapytanie o to, co inne, z czym spotykam się w momencie śmierci. Owa otwartość to otwartość na to, co przychodzi spoza mnie, z zewnątrz, i właśnie dlatego czas jest tutaj rozumiany jako relacja z tym, co inne, z tym, co nieskończone. Między innymi w taki właśnie sposób przejawia się diachronia czasu ${ }^{18}$. Moment śmierci odsłania pewną niesynchroniczność, ponieważ czas jawi się tu jako relacja z tym co inne, niepojmowalne, nieskończone. Ten czas dotyczył nas wcześniej jako nasze trwanie, ale w momencie śmierci pojawia się owa diachronia, o której Lévinas pisze:

Relacja z Odmiennym, które jednak jest nie-in-dyferentne, i gdzie diachronia tkwi jakby w innym-w-tym samym — tak, że Inne nie może wejść w To Samo. Wzgląd niepamiętnego dla nieprzewidywalnego. Czas jest owym Innym-w-Tym-Samym, a zarazem owym Innym, które nie może istnieć naraz z Tym Samym.

\footnotetext{
16 Ibidem, s. 16.

17 E. Lévinas, Całość i nieskończoność, s. 282.

18 O Lévinasowskiej diachronii czasu pisałam szerzej w artykule pt. Diachronia czasu-wieczne spóźnienie, [w:] Czas, przemijanie, wieczność, A. Bobko, M. Kozak (red.), Kraków 2008.
} 
Czas byłby więc niepokojeniem Tego Samego przez Inne, w którym To Samo nigdy nie może pojąć Innego, objąć go ${ }^{19}$.

Czas odsłania nam moment śmierci jako zapytywanie i jednocześnie niepokój. Będąc otwartym na to, co nowe, inne i nieznane, nie mogę osiąść w spoczynku, stąd niepokój. Wydaje się to być stanem jak najbardziej naturalnym, gdyż spotkanie z tym, co inne, odmienne i przychodzacce z zewnątrz mnie, zazwyczaj budzi w człowieku stan niepokoju, stan oczekiwania na... Dlatego też Lévinas opisuje pewną modalność czasu, która odsłania się w umieraniu, jako trwanie-w-stanie-czuwania. Czuwam w oczekiwaniu na to, co będzie. Nie osiadam w spoczynku, tylko wręcz przeciwnie: z ciekawością czekam, czuwając. Moje czuwanie nie może przerodzić się w sen. To dlatego już wcześniej Lévinas wspominał o bierności czasu rozumianej jako cierpliwość. Czas, który się odsłania w momencie śmierci, wymaga ode mnie czuwania, do którego niezbędna jest cierpliwość. Stan czuwania w oczekiwaniu na śmierć i wynikający z tego niepokój generują pewien absolutny stan bierności. Podmiot jest wycofany w sposób radykalny. Zapowiedź śmierci wymusza na podmiocie zwijanie się do środka, ponieważ ,śmierć zapowiada wydarzenie, nad którym podmiot nie panuje, wydarzenie, wobec którego podmiot nie jest już podmiotem"20. Pojawia się tu radykalna różnica między podejściem Lévinasa i Heideggera. Lévinas pisze o „niemożliwości możliwości”, a Heidegger o „możliwości niemożliwości”"21. Jedna z komentatorek Lévinasa, odnosząc się do jego stanowiska, pisze: „Byt, który stanął wobec śmierci, nie może już móc, opada go bierność — ta bierność nie jest modyfikacją możliwości, lecz absolutnym poddaniem. Komu? Nieprzejrzystej, niepochwytnej tajemnicy" 22 . W tym miejscu Lévinas bardzo wyraźnie odnosi się do Heideggera, u którego bycie-ku-śmierci było wyrazem najwyższej przytomności Dasein, weryfikatorem autentyczności lub nieautentyczności bycia. Lévinas interpretuje to tak, że w przekonaniu Heideggera „Jest to osiągnięcie przez Dasein ostatecznej możliwej egzystencji”23. Natomiast sam Lévinas widzi tę kwestię zupełnie inaczej.

\section{Cierpienie, ból i samotność umierania}

Bliskość śmierci (w czasie) podmiot odczuwa poprzez cierpienie. „W cierpieniu, równocześnie z niemożliwością odniesienia się do nicości, zawarta jest bliskość śmierci"24. Nie chodzi tylko o poczucie i wiedzę, że cierpienie może prowadzić do

${ }^{19}$ E. Lévinas, Bóg, śmierć, czas, s. 27.

20 E. Lévinas, Czas i to, co inne, s. 70.

${ }^{21}$ Lévinas pisze w tym kontekście: „Ale nieuchronność niebezpieczeństwa jest jednocześnie zagrożeniem i odroczeniem. Ponagla i pozostawia ciągle czas. Być bytem czasowym to jednocześnie być ku śmierci i mieć jeszcze czas, być przeciwko śmierci. Nieuchronność zagrożenia stawia mój byt pod znakiem zapytania i określa istotę mojego strachu. Ustanawia relację z chwilą, której wyjątkowy charakter nie polega na tym, że leży na progu nicości albo nowych narodzin, ale że w życiu oznacza niemożliwość wszelkiej możliwości"; idem, Całość i nieskończoność, s. 283.

${ }^{22}$ M. Chmura, Zanim umrze Iwan Iljicz. Perypetie podmiotu w filozofii E. Lévinasa, Warszawa 2007, s. 103.

${ }^{23}$ E. Lévinas, Czas i to, co inne, s. 70.

${ }^{24}$ Ibidem, s. 68. 
śmierci, że ją otwiera i przybliża, ale ,jakby istniała jeszcze wolna przestrzeń dla jakiegoś wydarzenia, jak gdyby należało się jeszcze o coś niepokoić, jak gdybyśmy byli u progu wydarzenia wykraczającego ponad to, które zostało do końca odsłonięte w cierpieniu. Struktura bólu rozciąga się gdzieś dalej, ku czemuś nieznanemu"25. Ból i cierpienie w wyraźny sposób spotykają się u Lévinasa w doświadczeniu umierania i niemożności ucieczki przed śmiercią. Co więcej, czytając jego opisy tego stanu, można odnieść wrażenie, że nie chodzi o ból fizyczny i cierpienie namacalne. To cierpienie absolutnej bezsilności wobec śmierci. To ból egzystencjalny, który „wbija mnie” w dno mojej egzystencji, z którego nie mogę się odbić. Francuski filozof opisuje ten stan słowami:

Ból wbija nas wtedy w byt. Nie doznajemy go tylko jako nieprzyjemnego wrażenia, które towarzyszy temu wbiciu, temu wtłoczeniu w byt. To wtłoczenie jest samym cierpieniem, bezwyjściowością fizycznego kontaktu. Cała dolegliwość cierpienia polega na niemożności ucieczki przed nim, na niemożności schronienia się w sobie przeciwko sobie, na odłączeniu się od wszelkiego żywego źródła — na niemożności wycofania $\operatorname{się}^{26}$.

Lévinas próbuje pokazać z jednej strony niepowtarzalność śmierci, z drugiej zaś jej dramatyzm w doświadczeniu cierpienia, ale i samotności w tym doświadczeniu. Śmierć prowadzi człowieka ku absolutnie nieznanemu, innemu, obcemu. Jest to doświadczenie absolutnej bierności, gdyż człowiek musi poddać się umieraniu, nikt go w tym nie zastąpi i właśnie dlatego jest to doświadczenie radykalnej samotności, a więc w pewnym sensie bólu i cierpienia. Człowiek zmierza ku nieznanemu, ku obszarowi, z którego nikt nie powrócił, poza wszelkim światłem.

Ten sposób zapowiadania się śmierci w cierpieniu, poza wszelkim światłem, jest doświadczeniem bierności podmiotu, pozostającego aktywnym nawet wtedy, gdy przerasta go jego własna natura, ale gdy zachowywał możliwość urzeczywistniania swego faktycznego stanu [...] śmierć zapowiada wydarzenie, nad którym podmiot nie panuje, wydarzenie, wobec którego podmiot nie jest już podmiotem ${ }^{27}$.

Wszelka aktywność człowieka zostaje mu odebrana. O ile jego naturą było wcześniej działanie, dynamizm, witalność, o tyle teraz w doświadczeniu absolutnej bierności musi zrezygnować z tego wszystkiego i oddać się temu, co radykalnie inne i obce. To w jakiś sposób jest sprzeczne z jego naturą, a więc musi generować doświadczenie cierpienia, bólu, niepewności i samotności. Lévinas określa moment śmierci jako „wstrząs bierności totalnej, w porównaniu z którą pasywność zmysłowości, która może przekształcić się w aktywność, jest tylko słabą imitacją bierności"28. Jednak oprócz doświadczenia radykalnej bierności, dużo miejsca poświęca doświadczeniu strachu i bólu, które towarzyszą umieraniu. Heidegger pisał o trwodze jako nastroju najbliższym śmierci: „trwoga przed śmiercią jest trwogą »przed « najbardziej własną, bezwzględną i nieprześcignioną możnością bycia. »Przed czym « tej trwogi to samo bycie-w-świecie. Jej »o co《 to wprost możność bycia jestestwa"29 i w dalszej kolejności odróżniał trwogę przed śmiercią od lęku przed utratą życia. Trwoga była pojmowana jako stan ontologiczny — nie jako

\footnotetext{
25 Ibidem.

${ }^{26}$ E. Lévinas, Całość i nieskończoność, s. 287.

27 E. Lévinas, Czas i to, co inne, s. 70.

${ }^{28}$ E. Lévinas, Całość i nieskończoność, s. 283.

${ }^{29}$ M. Heidegger, Bycie $i$ czas, s. 317.
} 
nastrojenie, żaden „przygodny i słaby nastrój jednostki”30, ale jako podstawowe położenie Dasein. Lévinas koncentruje się na strachu, który bardziej odpowiada stanowi egzystencjalnemu, wewnętrznemu nastawieniu podmiotu wobec tego, co obce, nieznane i przez to przerażające. Śmierć stawia moją egzystencję pod znakiem zapytania, a więc kwestionuje ją i zagraża jej. Dlatego „strach o mój byt, określający relację z moją śmiercią, nie jest strachem przed nicością, lecz strachem przed przemocą"31, to strach przed tym, co absolutnie nieprzewidywalne, poza moim zasięgiem, naznaczone tajemnicą i niepoznawalnością.

Mimo zupełnie różnych perspektyw (ontologicznej kontra relacyjnej) można jednak w tym miejscu pokusić się o dostrzeżenie pewnej wspólnej intuicji między Heideggerem a Lévinasem. Kiedy Heidegger pisze o niemożności zastępowalności w śmierci, to w jakiś sposób także odwołuje się do tragicznego doświadczenia samotności umierającej jednostki.

Wśród możliwości bycia wspólnego bycia w świecie znajduje się bez wątpienia zastępowalność jednego jestestwa przez inne [...] Ta możliwość zastępowania zupełnie jednak znika tam, gdzie chodzi o zastępowanie możliwości bycia, które stanowi dobieganie-kresu jestestwa i nadaje mu, jako takie, zupełność. Nikt nie może innemu odebrać jego umierania. Oczywiście, ktoś może ,iść na śmierć za innego". To jednak zawsze oznacza: oddać się w ofierze za innego „w imię określonej sprawy”. Takie umieranie za... nie może zaś nigdy oznaczać, że w ten sposób choćby w najmniejszym stopniu odjęto innemu jego śmierć ${ }^{32}$.

Niemiecki filozof w wyraźny sposób podkreśla nie tylko niemożność zastąpienia kogoś w jego umieraniu, wzięcia na siebie czyjejś śmierci, lecz również pewną fundamentalną konieczność samotnego zmierzenia się z tym doświadczeniem. „Każde jestestwo musi zawsze samo brać na siebie umieranie. Śmierć jest, jeśli »jest «, zawsze moja"33. Wydaje się, że w tym momencie Lévinas i Heidegger znajdują wspólny punkt porozumienia: jednostkowość, samotność i bierność doświadczenia śmierci. Jeżeli Heidegger powie: „Umieranie to nie zdarzenie, lecz fen omen, który należy rozumieć egzystencjalnie"34 — to Lévinas zapewne przyznałby mu rację, uzupełniając jednak to określenie o dodatkowy wymiar: metafizyczny i relacyjny, którego jednak u Heideggera nie znajdziemy. Dla Heideggera umieranie jest w pierwszej kolejności doświadczeniem ontologicznym, w którym chodzi przede wszystkim o dopełnienie pewnej całości, usunięcie pewnego zalegania, osiągnięcie pewnej zupełności (Gänze), dobieganie do $\mathrm{kresu}^{35}$. Co więcej, Lévinas upatruje w analizach śmierci i umierania u Heideggera przedłużenia tradycji perspektywy ego, a więc egoistycznego, totalnego postrzegania świata jedynie w perspektywie „Ja"36. A sam Lévinas nie chce zatrzymać się na analizie związku czasu i śmierci

30 Ibidem, s. 317.

31 E. Lévinas, Całość i nieskończoność, s. 283.

32 M. Heidegger, Bycie $i$ czas, s. 303.

33 Ibidem.

34 Ibidem.

35 „W jestestwie zawsze jeszcze coś zalega, co jako możność bycia jego samego nie stało się jeszcze »rzeczywiste«. Istota podstawowego ukonstytuowania jestestwa zawiera zatem ciągła nie zamkniętość. Taki brak całokształtu oznacza zaległość możności bycia”, M. Heidegger, Bycie i czas, s. 288.

36 Świadczyć mogłyby o tym choćby słowa Heideggera: „Prymarny moment troski, »samoantycypacja« oznacza przecież: jestestwo egzystuje zawsze ze względu na siebie samo. »Dopóki ono jest«, aż 
w kondycji samotnego człowieka. To zresztac kolejny zarzut pod adresem Heideggera, który w przekonaniu francuskiego filozofa ograniczył swoje analizy do samotnego Dasein zabieganego wokół siebie, zatroskanego jedynie o swoją egzystencję. Lévinas pokazuje, że autentyczne doświadczenie inności, fundamentalne zatroskanie dotyczy śmierci Innego. Relacja ze śmiercią Innego nie dotyczy wiedzy na temat śmierci drugiego człowieka ani doświadczenia tej śmierci w sensie unicestwienia bycia. Relacja ze śmiercią Innego jest wyjątkowa, ponieważ czas, w którym się ona dokonuje, odsłania „emocje, poruszenie, niepokój w dziedzinie tego, co nieznane"37. Lévinas, opisując wyjątkowość tej relacji, koncentruje się przede wszystkim na jej emocjonalności, która bynajmniej nie wynika z żadnej uprzedniej wiedzy. Ten czas, w którym przeżywam odejście kogoś mi bliskiego, budzi we mnie emocjonalność wcześniej mi nieznaną i nieogarniętą. Z jednej strony w tej emocji pojawia się respekt i szacunek dla śmierci, pojawia się także „emocja jako pytanie niezawierające elementów odpowiedzi. Pytanie, które zaszczepia się na głębszym stosunku do nieskończoności, którym jest czas (czas jako stosunek do nieskończoności)"38. Jakie to zapytywanie, które pojawia się w momencie śmierci drugiego człowieka, w odsłonie emocjonalności? Każdy z nas, kto przeżył śmierć bliskiej osoby, doskonale wie, jakie to zapytywanie, w postaci jakich pytań... i w postaci braku jakich odpowiedzi. Co jeszcze odsłania przed nami czas poprzez emocjonalny stosunek do śmierci innego? Lévinas odpowiada: „Strach i odwaga, lecz także, poza współczuciem dla innego i solidarnością z nim, odpowiedzialność za niego w nieznanym"39. To właśnie statusowi odpowiedzialności za Innego — także w kontekście śmierci — Lévinas poświęca najwięcej uwagi.

\section{Umieranie innych}

Można u Heideggera dopatrzeć się obecności Innego w doświadczeniu śmierci i umierania, kiedy niemiecki filozof pisze o „uderzającej śmierci innych”40. Jednak kontekst, w jakim przywołuje on umieranie Innego, jest nie do przyjęcia dla Lévinasa.

Tym bardziej uderzająca jest śmierć innych. Zakończenie jestestwa staje się wówczas dostępne „obiektywnie”. Może ono nabyć doświadczenia śmierci, zwłaszcza, że jest z istoty współbyciem z innymi. Ten „obiektywny” sposób dania śmierci musi umożliwić także ontologiczne wyodrębnienie całokształtu jestestwa ${ }^{41}$.

Dostrzeżenie przez Heideggera faktu, że inni również umierają, bynajmniej nie prowadzi go do wymiaru relacyjności umierania. Dla Lévinasa nie istnieje żadna obiektywność śmieci, a już na pewno obserwowanie odchodzenia innych nie przybliża mnie do tego fenomenu. Nie można „nabyć doświadczenia śmierci” przez

\footnotetext{
po swój kres, odnosi się do swej możności bycia” (ibidem, s. 298). Lévinas widzi u Heideggera „tylko ze względu na siebie samo" i ,odnoszenie się tylko do swej możności bycia”. Brakuje mu wymiaru relacyjnego, fundującego podmiot odniesienia do Ty, a więc perspektywy dialogicznej.

37 E. Lévinas, Bóg, śmierć, czas, s. 23.

38 Ibidem, s. 24.

${ }^{39}$ Ibidem.

${ }^{40}$ M. Heidegger, Bycie i czas, s. 300.

${ }^{41}$ Ibidem.
} 
towarzyszenie (Dabeisein) innym w ich umieraniu — jak to dalej będzie próbował opisać Heidegger.

Jeżeli śmierć nie jest tylko kresem, ale także zapytywaniem, to pytanie to fundamentalne ze swej natury — Lévinas kieruje się w stronę Innego. „Śmierć w sensie kresu, nie może wytyczyć całego znaczenia śmierci, jeśli nie staje się odpowiedzialnością za Innego"42. Zostaję włączony w śmierć Innego, bo śmierć Innego jest dla mnie pierwotnym doświadczeniem śmierci. W tym sensie pojawia się ona przede mną, jest ważniejsza niż moja własna śmierć, bo jest pierwsza nie tylko w porządku poznawczym, lecz także etycznym. Lévinas uważa, że czas należy przedstawiać na podstawie tej właśnie relacji, tego „szacunku dla śmierci Innego i tego zapytywania będącego relacją z nieskończonym"43. Według Lévinasa Heidegger szuka i znajduje doświadczenie śmierci jako śmiertelnego kresu, który potwierdza nicość, spoza której już nic nie przenika ${ }^{44}$. W tym sensie - w przekonaniu Lévinasa - Heidegger dostrzega relację czasu i śmierci jako całość, spójną, domkniętą poprzez dobrnięcie do kresu. Lévinas przyjmuje inną perspektywę: kwestionuje możliwość utworzenia całości z czasu i śmierci. Co więcej, dla Heideggera śmierć jest w pierwszej kolejności moją śmiercią. Dasein jako bycie rzucone w świat jest byciem ku śmierci, które wypełni się w momencie dobiegnięcia do kresu. Dla Lévinasa śmierć jest w pierwszej kolejności śmiercią Innego, za którego ja jestem odpowiedzialny. Lévinas pisze o tym bardzo mocno:

Czy śmiertelna nicość nie jest właśnie nagością twarzy bliźniego? „Nie dopuścisz się mordu!” to nagość twarzy. Czy bliskość bliźniego nie polega na mojej odpowiedzialności za jego śmierć? A więc moja relacja z Nieskończonym przeradza się w tę odpowiedzialność. Śmierć w twarzy drugiego człowieka jest modalnością, według której inność, przez którą To Samo zostaje poruszone, rozsadza swoją tożsamość Tego Samego pod postacią pytania, które w nim powstaje ${ }^{45}$.

Dochodzimy do centrum analiz Lévinasa na gruncie problematyki czasu i śmierci: jeżeli według Heideggera Dasein jest zapytywaniem o bycie w świecie, to Lévinas odpowiada, że odpowiedzią jest moja odpowiedzialność za śmierć Innego. Płaszczyzna analiz ontologicznych prowadzi do płaszczyzny etycznej, a w pewnym sensie też do metafizycznej. „Śmierć nie należy do świata. Zawsze jest skandalem i w tym sensie zawsze jest transcendentna w stosunku do świata" ${ }^{\prime 6}$. Śmierć stawia przed człowiekiem pytania nie z tego świata. Ich natura jest transcendentna, przychodzi z nieskończoności, ale odpowiedzi na te pytania nie są możliwe do odnalezienia tu i teraz. Dlatego Lévinas pisze o skandalu śmierci i jej przynależności do innego świata. Doświadczenie śmierci drugiego człowieka ukazuje tę perspektywę nad wyraz dobitnie. To właśnie relacja z Innym i jego pytający wyraz twarzy w umieraniu, stawiają także mnie i moje życie pod znakiem zapytania. Czas i śmierć, które spotykają się razem, otwierają przed człowiekiem przestrzeń

${ }^{42}$ E. Lévinas, Bóg, śmierć, czas, s. 52.

43 Ibidem, s. 53.

${ }^{4}$ Heidegger pisze na przykład: „Gdy zaś jestestwo »egzystuje« tak, że nic już w nim nie zalega, to tym samym stało się ono już-nie-byciem-tu-oto. Likwidacja zaległości bycia oznacza unicestwienie jego bycia", idem, Bycie i czas, s. 299.

45 E. Lévinas, Bóg, śmierć i czas, s. 136.

${ }^{46}$ Ibidem, s. 132. 
niepojmowalnej tajemnicy. „Czy poszukiwanie, pragnienie, pytanie nie oznaczaja braku odpowiedzi, to znaczy niewystarczalnej tożsamości albo czy nie są myślami o tym, co przewyższa myśl? — jeśli mamy prawo użyć zaimka to, który wskazuje treść proporcjonalną do myśli, korelat myśli, i jeśli tę relację myśli z bezmiernością można jeszcze nazwać myśleniem" ${ }^{47}$ — zastanawia się Lévinas, wyraźnie polemizując w podtekście z Heideggerem.

\section{Zakończenie: sens śmierci}

Jeżeli Lévinas prowadzi myślenie o śmierci na podstawie czasu, a tak sam deklaruje, to oczywiście pojawić się musi pytanie o sens śmierci. Lévinas przyznaje się w tym miejscu do fenomenologii śmierci, którą rozwija w swoich tekstach. Śledzacc myślenie Lévinasa, nasuwają się tu pewne oczywiste pytania: Czy sensu śmierci można szukać na postawie czasu? Czy ten sens nie ukazuje się w diachronii czasu rozumianego jako relacja z innym? Czy czas można rozumieć jako relację z innym? Czy czas można rozumieć jako relację z Innym, zamiast widzieć w nim relację z kresem? Czas oznacza zwrot tego samego ku Innemu. Ten zwrot oznacza w praktyce zwrot ku bliźniemu. „Odpowiedzialnością niedostępną, której pilność wskazuje mnie jako kogoś niezastępowalnego i jedynego"48. Ale czasem rządzi diachronia, a ja i Inny nie mogą się zsyntetyzować ani utożsamić. A więc jednak diachronia. „Niemożność ułożenia się na tym samym terenie, złożenia się w świecie, niemożność objawiająca się usunięciem gruntu spod moich nóg" ${ }^{49}$ — podsumowuje Lévinas. Wydaje się jednak, że to właśnie w relacji z Innym, z drugim człowiekiem, Lévinas odnajduje poszukiwany sens czasu i śmierci. Wymiar relacyjny, a szczególnie dialogiczny, jest tą perspektywą, która pozwala Lévinasowi spojrzeć dalej niż patrzył Heidegger. Podmiot nie może sam siebie zanegować, co w rozumieniu Lévinasa oznacza, że nie jest mu dana sama nicość nawet w wydarzeniu śmierci. Za to dane nam jest napotykanie innych ludzi, wchodzenie z nimi w relacje, budowanie więzi, nawiązywanie dialogu. Wydarzenie spotkania z Innym, określane mianem uspołecznienia jeśli dotyczy większej ilości relacji z innymi ludźmi, odsłania przede mną jakiś fundamentalny sens ludzkiej egzystencji. „Skoro czas konstytuuje się poprzez moją relację z innym, to jest czymś zewnętrznym względem mojej chwili, ale jest tė̇ czymś innym niż przedmiot kontemplacji. Dialektyka czasu jest właśnie dialektyką relacji z innym, to znaczy dialogiem, który należy rozpatrywać w innych kategoriach aniżeli kategorie samotniczego podmiotu"50 — pisze Lévinas. Skoro dialektyka czasu, a więc także śmierci, która jest następstwem i konsekwencją czasu, jest w swej istocie dialektyką relacji z drugim człowiekiem, to znaczy, że właśnie tutaj kryje się sens utożsamiany przez Lévinasa z dialogiem. To nie czas określa mnie, przychodząc z zewnątrz. To ja będąc w relacji z bliźnim konstytuuję czas, który między nami przepływa - który nas zbliża do siebie lub oddala. To

\footnotetext{
47 Ibidem, s. 134.

48 Ibidem, s. 130.

49 Ibidem.

${ }^{50}$ E. Lévinas, Istniejacy i istnienie, tłum. J. Margański, Kraków 2006, s. 152.
} 
właśnie dlatego dialektyka czasu jest utożsamiona z dialektyką relacji (u Lévinasa etycznej, a więc także metafizycznej). Człowiek mierzy się z czasem, a więc także ze śmiercią, nie w swoim samotnym byciu i w swoim dobieganiu-do-kresu, ale zawsze poprzez bycie z Innymi, w swojej relacyjności zbudowanej z innymi ludźmi. Owszem, Lévinas dostrzega obecność wątku „my” rozumianego jako „bycie z innymi" u Heideggera, ale nie przyjmuje takiej interpretacji jaka przedstawił Heidegger. Zarzuca mu, że w jego rozumieniu bycie z innymi zawsze oznaczało jakieś stopienie się w całość, prowadziło do utożsamienia się z innymi prędzej czy później i utworzenie jakiejś anonimowej całości ${ }^{51}$. Relacyjność, która funduje czas, według Lévinasa opiera się na zachowaniu różnicy, na szacunku dla inności i utrzymaniu odrębności. Dialog, który stanowi centrum relacyjności, jest możliwy tylko przy zachowaniu separacji uczestników relacji, przy wzajemnym dystansie, który umożliwia zbliżanie się do siebie. Pojęcie jednolitej wspólnoty, oparte na dążeniu do scalenia się z innymi, wykluczałoby Lévinasowskie rozumienie dialogu. Co więcej, Lévinas również bardzo krytycznie odnosi się do „spoiwa”, które w myśli Heideggera miałoby jednoczyć ludzi i łączyć ich w większą całość.

Taką zbiorowością ,z" pozostaje także Heideggerowskie Miteinandersein i w swojej autentycznej formie skupia się wokół „prawdy”. Jest zbiorowością skupiajaccą się wokół czegoś wspólnego. [...] Tej zbiorowości przeciwstawiamy uprzednią wobec niej zbiorowość, jaką tworzą ,,ja” i „ty”. Nie zakłada ona uczestnictwa jakiegoś trzeciego członu - pośredniczącej osoby, prawdy, dogmatu, dzieła, zawodu, interesu, wspólnego zamieszkiwania, posiłku - to znaczy nie jest ona wspólnotą. Jest budzącą grozę relacją twarzą w twarz, w której nie ma żadnego pośrednika, żadnej mediacji ${ }^{52}$.

Sens, który kryje się w relacji czasu i śmierci odsłania się w mojej relacji z Innym, a najpełniej w naszej dialogiczności. W takiej konstrukcji nieuprawnione jest szukanie wspólnej całości, która w jakiś sposób miałaby nas chronić, łagodzić ból i cierpienie mierzenia się z czasem, przemijaniem, umieraniem aż po śmierć. Dialektyka czasu będąc w swej istocie dialektyką relacji z innym realizuje się w dialogu, w byciu twarzą w twarz, bez pośredników, pomocników, mediacji i uproszczeń. Podłożem takiej dialektyki jest zawsze konfrontacja z innością ${ }^{53}$. Tylko tutaj mogę odkryć sensowność powiązania czasu i śmierci oraz próbować zrozumieć czas jako sposób bycia mnie jako istotny śmiertelnej.

51 Odwołując się do myśli Heideggera, komentuje ją tak: „Przyjmuje się, że moja relacja z innym prowadzi do utożsamienia mnie z nim, zatapiając nas w zbiorowym wyobrażeniu, we wspólnym ideale lub wspólnym geście. Owa zbiorowość, przemawiająca jako »my«, widzi innego u swego boku, a nie przed sobą. Ona też tworzy się wokół trzeciego elementu, który występuje w roli pośrednika, który nadaje wspólnocie wspólność"; E. Lévinas, Istniejący i istnienie, s. 153.

52 Ibidem, s. $153-154$.

${ }^{53}$ Lévinas pisze tutaj o inności Innego — drugiego człowieka — w słowach: „Inny jako taki nie jest jakimś alter ego. Jest tym, czym ja nie jestem. [...] Inny to bliźni - lecz bliskość nie oznacza degradacji, nie jest też żadnym etapem na drodze do zespolenia" (ibidem, s. 154-155). To jasno pokazuje, że chodzi Lévinasowi o inność radykalną i absolutną utożsamioną z drugim człowiekiem, tym, którego napotykam $\mathrm{w}$ relacji, a potem $\mathrm{w}$ dialogu. 


\section{Bibliografia}

Chmura M., Zanim umrze Iwan Iljicz. Perypetie podmiotu w filozofii Emmanuela Lévinasa, Warszawa 2007.

Galarowicz J., Martin Heidegger: genialny myśliciel czy szaman?, Kraków 2014.

Heidegger M., Bycie i czas, tłum. B. Baran, Warszawa 2005.

Heidegger M., Odczyty i rozprawy, tłum. J. Mizera, Warszawa 2007.

Lévinas E., Bóg, śmierć i czas, tłum. J. Margański, Kraków 2008.

Lévinas E., Całość i nieskończoność, tłum. M. Kowalska, Warszawa 2002.

Lévinas E., Czas i to, co inne, tłum. J. Migasiński, Warszawa 1999.

Lévinas E., Istniejący i istnienie, tłum. J. Margański, Kraków 2006.

Strzelecki R., Ethos $i$ wolność. W poszukiwaniu etycznej wymowy „Bycia i czasu” Martina Heideggera, Kraków 2006. 